\title{
Hackathons and Libraries
}

The Evolving Landscape 2014-2020

Meris Mandernach Longmeier

\section{ABSTRACT}

Libraries foster a thriving campus culture and function as "third space," not directly tied to a discipline. ${ }^{1}$ Libraries support both formal and informal learning, have multipurpose spaces, and serve as a connection point for their communities. For these reasons, they are an ideal location for events, such as hackathons, that align with library priorities of outreach, data and information literacy, and engagement focused on social good. Hackathon planners could find likely partners in either academic or public libraries as their physical spaces accommodate public outreach events and many are already providing similar services, such as makerspaces. Libraries can act solely as a host for events or they can embed in the planning process by building community partnerships, developing themes for the event, or harnessing the expertise already present in the library staff. This article, focusing on years from 2014 to 2020, will highlight the history and evolution of hackathons in libraries as outreach events and as a focus for using library materials, data, workflows, and content.

\section{INTRODUCTION}

As a means of introduction to hackathons for those unfamiliar with these events, the following definition was developed after reviewing the literature. Hackathons are time-bound events where participants gather to build technology projects, learn from each other and experts, and create innovative solutions that are often judged for prizes. While hacking can have negative connotations when it comes to security vulnerabilities, typically for hackathon events hacking refers to modifying original lines of code or devices with the intent of creating a workable prototype or product. Events may have a specific theme (use of a particular dataset or project based on a designated platform) or may be open-ended with challenges focused on innovation or social good. While hackathons have been a staple in software and hardware design for decades, the first hackathons with a library focus were sponsored by vendors, focused on topics such as accessibility and adaptive technology for their content and platforms. ${ }^{2}$ Other industry hackathons focused on re-envisioning the role of the book in 2013 and 2014. ${ }^{3}$

As hackathons became more popular at colleges and universities, library participation evolved from content provider to event host. These partnerships were beneficial to libraries interested in shifting the perception of libraries from books to newer areas of expertise around data and information literacy. However, many libraries realized that by partnering in planning the events greater possibilities existed to educate participants about library content and staff expertise. Some examples include working with public library communities to highlight text as data, having academic subject librarians work with departmental faculty to embed events within curriculum and assignments, and for both academic and public libraries to promote library-produced and publicly available datasets. ${ }^{4}$

Meris Mandernach Longmeier (longmeier.10@osu.edu) is Head of Research Services, The Ohio State University Libraries. (C) 2021. 
There are many roles that libraries can take in these events. Libraries can act as event hosts where they provide the space at a cost or for free. ${ }^{5}$ In other cases, library staff become collaborators and in addition to space may assist with planning logistics, judging, building partnerships, and have some staff present at the events. ${ }^{6}$ In public libraries this often includes building relationships with the city or specific segments of the community based on the theme of the event. On college campuses, it may be a partnership with a specific disciplines or campus IT or an outside sponsor. In this way, the libraries are building and sustaining the event due to aligned priorities with the other partners. Another option would be for the library to be the primary sponsor, where the library may provide prizes, the theme for the hackathon, as well as many of the items listed above. ${ }^{7}$ However, instead of specific categories, it should be viewed as a continuum of partnership and the amount of involvement with the event should align with the library's priorities of what it hopes to accomplish through the event. How involved in event planning specific libraries want to be may depend on the depth of the existing partnerships as well as how many resources the library wants to commit to the event.

Libraries have always existed as curators and distributors of knowledge. Some libraries are using hackathons to advance both their image and their practices. Libraries are evolving into new roles and have grown to support more creative endeavors, such as the maker movement. This shift of libraries from book-provider to social facilitator and information co-creator aligns with hackathon events. The physical spaces themselves are ideal to support public outreach events and libraries are already providing makerspaces or similar services that would overlap with a hackathon audience. ${ }^{8}$ Additionally, the spaces afforded by libraries allow flexibility and creativity to flourish, ideas to be exchanged, and different disciplines to mingle and co-produce. Library staff focused on software development may have projects that would benefit from outside perspectives as well.

In recent years libraries have become stewards of digital collections that can be used and reused in innovative ways. Many libraries have chosen Wikipedia edit-a-thons as a means of engaging with the public and enhancing access to materials. ${ }^{9}$ Similarly, the collections-as-data movement is blossoming and allowing galleries, libraries, archives, and museum (GLAM) institutions to rethink the possible ways of interacting with collections. Many public libraries are partnering with local or regional governments to build awareness of data sources and build bridges with the community around how they would like to interact with the data. ${ }^{10}$ Additionally, as data science continues to grow in importance in both public and academic libraries, data fluency, data cleaning, and data visualization could be themes for a hackathon or data-thon. ${ }^{11}$

For those unfamiliar with these events, table 1 provides some generalized definitions created by the author of the different types of events and their intended purpose. For some organizations, there are ways to support these events that consume fewer resources or require less technical knowledge, such as an edit-a-thons or code jams. 
Table 1. Defining common hackathon and hackathon-like events, purpose, and typical size of events

\begin{tabular}{|c|c|c|c|}
\hline $\begin{array}{l}\text { Type of } \\
\text { event }\end{array}$ & Definition & Purpose & Size of event \\
\hline Hackathon & $\begin{array}{l}\text { A team-based sprint-like event } \\
\text { focused on hardware or } \\
\text { software that brings together } \\
\text { programmers, graphic } \\
\text { designers, interface designers, } \\
\text { project managers or domain } \\
\text { experts; can be open ended idea } \\
\text { generation or for a specific } \\
\text { provided theme }\end{array}$ & $\begin{array}{l}\text { Build a working } \\
\text { prototype, typically } \\
\text { software }\end{array}$ & $\begin{array}{l}\text { Up to } 1,000 \\
\text { participants, } \\
\text { usually determined } \\
\text { by space available }\end{array}$ \\
\hline Idea Fest & $\begin{array}{l}\text { Business pitch competition } \\
\text { where individuals or teams pitch } \\
\text { a solution or new company } \\
\text { (startup) idea to a panel of } \\
\text { judges }\end{array}$ & $\begin{array}{l}\text { Deliver an elevator } \\
\text { pitch for an idea, } \\
\text { could be to secure } \\
\text { funding }\end{array}$ & $<100$ \\
\hline $\begin{array}{l}\text { Coding } \\
\text { Contest or } \\
\text { Code Jam }\end{array}$ & $\begin{array}{l}\text { An individual or team } \\
\text { competition to work through } \\
\text { algorithmic puzzles or on } \\
\text { specific code provided }\end{array}$ & $\begin{array}{l}\text { Learning to code or } \\
\text { solve challenges } \\
\text { through coding; may } \\
\text { produce a pitch at } \\
\text { the end rather than a } \\
\text { product }\end{array}$ & $20-50$ \\
\hline $\begin{array}{l}\text { Edit-a- } \\
\text { thon }\end{array}$ & $\begin{array}{l}\text { An event where users improve } \\
\text { content in a specific online } \\
\text { community; can focus on a } \\
\text { theme (art, country, city) or type } \\
\text { of material (map) }\end{array}$ & $\begin{array}{l}\text { Improving } \\
\text { information in online } \\
\text { communities such as } \\
\text { Wikipedia, } \\
\text { OpenStreetMap, or } \\
\text { LocalWiki }\end{array}$ & $20-100$ \\
\hline Datathon & $\begin{array}{l}\text { A data-science-focused event } \\
\text { where participants are given a } \\
\text { dataset and a limited amount of } \\
\text { time to test, build, and explore } \\
\text { solutions }\end{array}$ & $\begin{array}{l}\text { Usually a } \\
\text { visualization or } \\
\text { software } \\
\text { development around } \\
\text { a particular dataset }\end{array}$ & $50-100$ \\
\hline Makeathon & Hardware focused hackathon & $\begin{array}{l}\text { Build working } \\
\text { prototype of } \\
\text { hardware }\end{array}$ & $\begin{array}{l}\text { Up to } 300 \\
\text { participants }\end{array}$ \\
\hline
\end{tabular}

\section{METHODS}

To find articles in the library and information science literature related to hackathons and libraries, the author searched the Association for Computing Machinery (ACM) Digital Library, Scopus, Library Literature and Information Science, and Library and Information Science and Technology Abstracts (LISTA) databases. In Scopus and the ACM Digital Library, the most successful searches included the following: (hackathon* OR makeathon*) and library; in Library Literature and Information Science and LISTA databases, the most successful searches included: 
hackathon OR makeathon OR "coding contest." The author also searched Google Scholar in an attempt to locate other studies or reports, some of which came from institutional repositories. While this search strategy was not meant to be exhaustive, it uncovered many articles about hackathons and libraries and others were found by chaining citations in the articles reference lists. Based on search locales, international articles were found but only those where the text was available in English were included which meant that articles from Asia, Africa, and the Global South may have been inadvertently overlooked. Only two of the articles found in the search results were not held in library locations, did not use library/archival materials, or were not an outreach event where library staff were integral in planning (these were discarded.)

\section{FINDINGS}

The author grouped the literature into two categories: library as place and library as source. In the realm of library as place, the literature consisted of reporting on hackathons where the library was the host location for the event, those where the hackathon was an outreach event, and those where the hackathon was an extension of the libraries' teaching/education mission. For most of these articles the majority were case studies and often shared tips for other libraries to consider when hosting a hackathon in library spaces.

The second category, those that use library as source, focused on highlighting library spaces or services, workflows, or collections as the theme of the events. Additionally, there were a few articles in the second category that discussed how to prepare or clean library data or library sources before the event to ensure that participants were able to use the materials during the time-bound event. In some cases where the source materials were from the libraries, the event also occurred in the library; thus, some articles fit into both categories and are highlighted in both sections.

\section{Results: Library as Place}

The following summaries of hackathons and libraries as places for events will be grouped into two subgenres: library spaces and outreach events. Libraries, both public and academic, are ideal locations for hosting large, technology-driven events given the usual amenities of ample parking, ubiquitous Wi-Fi, adequate outlets, and at times already having 24-hour spaces built into their infrastructure. More and more libraries are offering generous food and drink policies, a benefit as sustenance is a mainstay at these multiday events. Additionally, libraries already host a number of outreach events and serve as a community information hub.

Using Libraries as Event Hosts for Hackathons

A number of articles detail the use of library spaces to host hackathon events. ${ }^{12}$ The University of Michigan Library, a local hackerspace (All Hands Active), and the Ann Arbor District Library teamed up to host a hackathon focused on Oculus Rift. ${ }^{13}$ This event grew out of a larger partnership with the community and sought to mix teams to include participants from all three areas. The 2018 article by Demeter et al. highlights lessons learned from Florida State University Library and many of the planning steps involved when hosting large outreach events in library spaces. ${ }^{14}$ While the library initially hosted a 36-hour event, HackFSU, as a favor to the provost in the first year, they continue to host the event, providing library staff as mentors and logistical support. After the first year they started charging the student organization for use of the space and direct staffing costs for the hours beyond normal operating hours. While focused primarily on providing a central campus space, the library also sees it as a way to highlight the teaching and learning role of the library. Similarly, Nandi and Mandernach detail the steps involved in planning 
hackathon events and some benefits of choosing the library as a location for the event. ${ }^{15}$ At Ohio State, hackathon events in 2014 and 2015 were held in the library due to twenty-four-hour spaces, interest by the libraries in supporting innovative endeavors on campus, and a participant size (100-200 attendees) that could be accommodated in the space. Other events chose academic libraries as locations for hackathons due to their central location on campus. ${ }^{16} \mathrm{An}$ initial summary of library hackathons was captured by R. C. Davis who detailed that libraries may be motivated to host such events as they align with library principles of "community, innovation, and outreach."17 She points out that libraries are ideal locations because of small modular workspaces paired with a large space for final presentations. Additionally, adequate and sufficiently strong Wi-Fi or hardwired connections, a multitude of power outlets, and 24-hour spaces are appealing for these kinds of events. Event planners should know that the necessities include free food and multidisciplinary involvement. Davis details ways to plan smaller events, such as code days or edit-a-thons, if staffing does not allow for a large hackathon event. In all cases, the libraries serve a purpose to either campus or community as the location and sometimes also provide staff for the events.

\section{Hackathons as Library Outreach}

Hackathon events are a great way to reach out to the community and provide a fresh look into libraries as purveyors of information focused on more than books. At the 2014 Computers in Libraries conference, Chief Library Officer Mary Lee Kennedy delivered a keynote sharing stories of the New York Public Libraries experiences hosting Wikipedia editathons and other hackathons at various branches since $2014 .{ }^{18}$ The goals for these outreach events were to highlight strategic priorities around making knowledge accessible, re-examine the library purpose, and spark connections. Early library hackathon events focused on outreach included topics of accessibility or designing library mobile apps. ${ }^{19}$ More recent events have focused on outreach but with an eye toward sharing content as part of the coding contest. ${ }^{20}$ Even library associations have hosted preconference hacking events to highlight what libraries are doing to foster innovation. ${ }^{21}$

The Future Libraries Product Forge, a four-day event, was hosted in collaboration with the Scottish Library and Information Council and delivered by Product Forge, a company focused on running hackathons that tackle challenging social issues. The 2016 event focused specifically on public libraries in Scotland and seven teams, comprised mainly of students from a local university, worked with public library staff and users as well as regional experts in technology, design, and business. ${ }^{22}$ The goals of the event were to raise awareness of digital innovation with library services, generate enthusiasm for approaches to digital service design, and codesign new services around digital ventures. Participants created novel products including digital signage, a game for young readers, a tool for collecting user stories about library services, and an app to reserve specific library spaces.

Another common focus for library hackathon outreach events is the theme of data and data literacy. In July 2016, the Los Angeles Public Library hosted the Civic Information Lab's Immigration Hackathon. ${ }^{23}$ This outreach event gathered 100 participants to address local issues around immigration. The library, motivated by establishing itself as a "welcoming, trusting environment," wanted to be a "prominent destination of immigrant and life-enrichment information and programs and services." ${ }^{24}$ Newcastle libraries ran two-day-long events focused on promoting data they released under an open license as part of the Commons are Forever project. ${ }^{25}$ They used both events to educate users about tools such as GitHub, a GIF-making session with historical photographs, and data visualization tools. Similarly, Toronto Public Library hosted a series of open data hackathons to highlight the role of the libraries in civic issue 
discourse, data literacy, and data education. ${ }^{26}$ Their events combined the hackathon with other panel presentations and resources focused on mentorship and connection-building in the technology sector. The library also used the event to promote their open data policy, build awareness around the data provided by the library for the community, and highlight their role in facilitating conversations around civic issues through data literacy and data education.

Edmonton Public Library hosted its first hackathon in 2014 for International Open Data Day. One of the main drivers was to build the relationship with their local government. ${ }^{27}$ They built their event around the tenets laid out in the Open Data Hackathon How-to Guide and by a blog post about the City of Vancouver's 2013 International Open Data Day Hackathon. ${ }^{28}$ They took a structured approach to documenting expectations of both partners around areas such as resources, staffing, and costs, which served as a roadmap for the hackathon and the partnership. The library provided the event space, coffee and pizza, an emcee, tech help and Wi-Fi, door prizes and "best idea" prize, and promotional material. The city recruited participants and provided an orientation, promotional banners, and a keynote. The event led to a deeper partnership with the city and additional hacking events. In these ways, the hackathon served a greater purpose of community building and awareness around data, the role the library plays in interpreting data, and how the libraries serve as a resource hub to the community.

Events Supporting Library Teaching Mission

At academic institutions, the events often focus on outreach to their own campus community. In 2015, Adelphi University hosted their first hackathon and the libraries funded the event themselves rather than seeking outside funding. ${ }^{29}$ The article details the considerable lessons learned through the process as well as a step-by-step guide to planning a smaller event. Similarly, York University Science and Engineering Library hosted hackfests in the library and embedded an event as part of an introductory computer science course. ${ }^{30}$ Shujah highlighted some of the benefits to the library hosting a hackathon included: establishing libraries as part of the research landscape, providing a constructive space for innovation and innate collaborative environment, highlighting the commitment to openness and democratizing knowledge, and acknowledging the library's role in boosting critical thinking and information literacy concepts. Shin, Vela, and Evans highlight a community hackathon at Washington State University College of Medicine where a group of librarians from multiple institutions staffed a research station throughout the event. ${ }^{31}$ While the station was underutilized by participants, as only seven questions were asked during the event, the libraries deemed their participation a success as it worked as an outreach and promotion mechanism for both library services and expertise.

At some public libraries, the focus of the hackathon is on education and teaching basic coding skills. Whether called a coding contest, hackathon, or tech sandbox, there are opportunities for programming with a focus on learning and skill-building and fun. ${ }^{32}$ Santa Clara County Library district used a peer-to-peer approach for mentoring and hosted a hackathon in 2015 for middleand high-school students. ${ }^{33}$ The library staff facilitated the event planning and recruited judges from the community, but the bulk of the event was coordinated by the students.

Considerations When Hosting Events in Library Spaces

A couple of substantive reports provide overarching recommendations and considerations for hosting hackathons in library spaces, including planning checklists, tips on getting funding, building partnerships with local community officials, and thinking through the event systematically. Recently, the Digital Public Library of America (DPLA) created a hackathon 
planning guide that details a number of logistical issues to address during the planning phases, both pre- and post-event. ${ }^{34}$ This report highlights specific considerations for galleries, libraries, archives and museums that are looking to host a hackathon. After hosting a successful hackathon, librarians at New York University created a LibGuide called Hack Your Library which is a planning guide for other libraries considering hosting a similar event. ${ }^{35}$ The Engage Respond Innovate Final Report: The Value of Hackathons in Public Libraries was put together following an event the Carnegie UK Trust sponsored. ${ }^{36}$ This guide highlights some of the challenges present with hackathons, including: intellectual property of the creations, prizes, participant diversity, and complications that arise from either approach of using specific themes or open-ended challenges. It also highlights some of the main reasons a library should consider hackathons and other coding events, including ways to promote new roles of libraries within communities, promote specific collections, capitalize on community expertise, gain insight about users, help users build new skills and improve digital literacy, and develop tools that increase access to materials. Finally, the report points out that hosting an event will not be the only solution for a library's innovation problem. Yet if the library is clear on why it wants to hold a hackathon, being planful about expectations and outcomes the library is trying to achieve will increase the chances for success.

\section{Results: Library as Source}

The other category of articles about hackathons and libraries focuses on the library as the source for the challenge or theme of the hackathon. The following summaries highlight articles include those where the libraries provided the challenges around library spaces or services, library datasets, workflows or collections as the theme for the hackathon. This section also details steps involved in cleaning data for use/re-use in time-bound events.

Using Hackathons to Improve Library Services and Spaces

A few articles discuss libraries that proposed hackathon themes around improving library services. A 2016 article describes how Adelphi University Libraries hosted a hackathon and provided the theme of developing library mobile apps and web software applications. ${ }^{37}$ The winning student team created an app for library group study meetups. Similarly, the librarians from University of Illinois tried three approaches for library app development: a student competition, a project in a computer science course, and a coding camp. With the adventure code camp, students co-designed with librarians over the course of two days. ${ }^{38}$ They advertised to specific departments and courses and ten students were selected with six ultimately participating in the two-day coding camp. Students were sent a package of library data, available APIs, and brief tutorials on coding languages that may be useful. Mentors and coaches were available throughout the coding camp. The authors provided tips for others trying to replicate their approach as well as insights from the students about interest in developing apps that include library data but that don't solely focus on library services. The following year the librarians hosted a coding contest focused specifically on app development related to library services and spaces. ${ }^{39}$ The library sponsored the event and served as both a traditional client and partner in the design process. Ultimately six teams with a total of 26 individuals participated and each app was "required to address student needs for discovery of and access to information about library services, collections, and/or facilities" but not duplicate existing library mobile apps. They based their approach on Massachusetts Institute of Technology's entrepreneurship competition. Through this process, co-ownership was preferred and many teams set up a licensing agreement as part of the competition to handle intellectual property for the software. Students had two weeks to complete the apps and were judged by both library and campus IT administration. This article details what 
they learned through the process given the amount of attrition from selection of teams to final product presentations.

The New York University School of Engineering worked with the libraries and used a hackathon theme of noise issues to coincide with the renovation of the library. ${ }^{40}$ The libraries created a LibGuide to provide structured information about the event itself

(https://guides.nyu.edu/hackdibner). They used the event to market the new maker space and held workshops there leading up to the event. In the inaugural year they held the event over the course of two semesters and saw a lot of attrition due to the event length. In the second year, following focus groups with participants, they designed a library hackathon with four goals: 1) appeal to a large base of the student population, 2) create a triangle of engagement between the student and the library, the library and the faculty, and the faculty and the students, 3) provide an adaptable model to other libraries, and 4) highlight the development of student information literacy skills. ${ }^{41}$ The second year's approach required more work by the participants due to pitching an initial concept, providing a written proposal, and giving a final presentation. Library staff and guest speakers offered workshops to help students hone their skills. The planners evaluated the event through surveys and student focus groups. Overall the students applied what they learned about information literacy and were highly engaged with the codesign approach to library service improvements.

Similarly, McGowan highlights two hackathons at Purdue that focused on inclusive healthcare and how the libraries applied design thinking processes as part of the events. ${ }^{42}$ The librarian wanted to encourage health sciences students to examine health data challenges. To examine this issue, she applied the Blended Librarians Adapted Addie Model (BLAAM) as a guide to developing a service to prepare students to participate in a hackathon. A number of pre-event training sessions were held in the libraries and covered topics such as research data management, OpenRefine and data cleaning, Gephi for data visualization, and JavaScript. While this initial approach was in tandem with the hackathon events, students reported that they needed assistance in finding and cleaning datasets for use. In this case, developing library services to prepare for hackathon events ended up out of alignment with both the library's mission and the participants' expectations.

\section{Using Library Materials for Hackathon Themes}

Several events have focused on library as source where the library's materials or processes serve as the theme of the hackathon, particularly around digital humanities (DH) topics. ${ }^{43}$ In September 2016, over 100 participants worked with materials from the special collections of Hamburg State and University Library, a space that serves both the university and the public. ${ }^{44}$ It followed the process established by Coding Da Vinci (https://codingdavinci.de/en), an event that occurred in 2014 and 2015. The event at Hamburg State and University Library had a kick-off day for sharing available datasets, brainstorming projects using library materials, and team building opportunities. The event had a second day of programming and then teams had six weeks to complete their projects. Some exemplary products included a sticker printer that would print old photographs, a quiz app based on engraving plates, and using a social media platform to bring the engravings to the public. The event was successful and resulted in opening additional data from the institution.

Several examples focus on highlighting digital humanities approaches as part of the events. In 2016, four teams from across European institutions participated over five days in Kibbutz Lotan in the Arava region of Israel to develop linguistic tools for Tibetan Buddhist studies with the goal of 
revealing their collections to the public. ${ }^{45}$ The planning team recruited international scholars to participate in prestructured teams (teams consisted of computer scientists as well as a Tibetan scholar) in Israel. Although it was less of a traditional hackathon, this event being more akin to an event/coding contest around a specific task, it highlighted tools and methods for understanding literary texts. The format of the event for encouraging interdisciplinary efforts in the computational humanities was deemed successful and it was repeated the next year on manuscripts and computer-vision approaches. Recently the University of Waterloo detailed a series of datathons using Archives Unleashed to engage the community in an open-source digital humanities project. ${ }^{46}$ The goal of the events was to engage DH practitioners with the web archive analysis tools and attempt to build a web archiving analysis community.

In 2016, the American Museum of Natural History in New York hosted their third annual hackathon event, Hack the Stacks, with more than 100 participants. ${ }^{47}$ The event focused on creating innovative solutions for libraries or archives and to "animate, organize, and enable greater access to the increasing body of digitized content." Ten tasks were available for participants to work on and ranged from a unified search interface, reassembling fragments of scientific notebooks, and creating timelines of archival photos of the museum itself. In addition to planning the tasks, the library staff ensured that the databases and applications could handle the additional traffic. A multitude of platforms were provided (Omeka, dSpace, the catalog, APIs, ArchiveSpace, etc) for hackers to use. All prototypes that were developed were open source and deposited on GitHub at "Hack the Stacks." ${ }^{48}$

Some cultural institutions have used hackathons as a means of outreach and publicity and then have showcased the outputs at the museums. Vhacks, a hackathon at the Vatican, was held in 2018 and gathered 24 teams from 30 countries for a 36 -hour event. ${ }^{49}$ The three themes for the event focused on social inclusion, interfaith dialogue, and migrants and refugees. A winner was announced for each thematic area and sponsors enticed participants to continue working on projects by having a venture capitalist pitch a few weeks after the event. Another program, Museomix, concentrates on a three-day rapid prototyping event where outputs are highlighted in the museum or cultural institution..$^{50}$ This event has happened annually in November since 2011 and the goal is to create interdisciplinary networks and encourage innovation and community partnership.

Improving Library Workflows and Processes

Other hackathons have focused on library staff working on library processes themselves. Bergland, Davis, and Traill detail a two-day event, CatDoc Hack Doc, hosted by the University of Minnesota Data Management and Access department focused on increasing documentation by library staff. ${ }^{51}$ This article details logistics of preparing for the event as well and a summary of the work completed. They based their approach on the Islandora Collaboration Group's Template on how to run a Hack/Doc. ${ }^{52}$ They were pleased with the workflow overall, refined some of the steps, and held it again for library staff the following year. Similarly, Dunsire highlights using a hackathon format to encourage adoption of a cataloging approach of Research Description and Access (RDA) through a "Jane-athon." ${ }^{33}$ Events occurred at library conferences or in conjunction with other hackathon events, such as the Thing-athon at Harvard, with the intention of promoting the use of RDA, to help users understand the utility of RDA, and to spark discussions. This approach proved useful in uncovering some limitations with RDA as well as valuable feedback that could be incorporated into its ongoing development. 


\section{Considerations When Using Libraries as Source}

If libraries are interested in hosting a hackathon where the library plays a more central role, there are several options of ready-to-use library and museum data that could allow the host to also serve as the content provider. The Digital Public Library of America released a hackathon guide, GLAM Hack-in-a-box: a short guide for helping you organize a GLAM hackathon with several sources at the end for finding data related to libraries. ${ }^{54}$ The University of Glasgow began a project called the Global History Hackathons that seeks to improve access and excitement around global history research. ${ }^{55}$ Additionally, Candela et al. detail the new array of sources for sharing GLAM data for reuse in multiple ways, including using data in hackathon projects. ${ }^{56}$ Planners could look to the collections-as-data conversations for other data sources that could be adapted for hackathon projects. ${ }^{57}$ When thinking about hackathons and cultural institutions, sustainability of projects and choice of platforms is an important consideration for planners. ${ }^{58}$ Ultimately, the top priority when providing a dataset is to ensure that it is clean and enough details about the dataset are available for participants to make use of it in their designs given the time constraints of most events.

\section{DISCUSSION}

Hackathons often have a dual purpose of educating the participants and serving as an advertisement for the sponsor for either a platform or content. Participants will develop a working prototype or improving their coding abilities; sponsors, including libraries, can benefit from rapid prototyping and idea generation using either their platforms or content. While usable apps or new ideas are a welcome outcome, even if the applications are not used, the events still feed into the larger goal of marketing libraries and their data, building relationships with local communities, or drawing attention to social good.

There are benefits to libraries in either hosting or collaborating on the events. In both areas, those of library as space and library as source, hackathons help realign user expectations of libraries. If libraries choose to become involved with hackathons or other coding or data contests, the library should be deliberate in its goals and intended outcomes as those will help shape both the event and its planning. Libraries are naturally aligned with teaching and learning, are already offering co-curricular programming, and typically serve as physical and communication hubs for campus. Libraries already prioritize outreach and engagement with constituents both on campuses and in the community. Therefore, when programs align with library priorities of data literacy, data fluency, and information evaluation, it is a natural fit to propose involvement in hosting hackathons. Many libraries are able to customize their spaces, services, and vendor interfaces, which is a benefit when thinking about having libraries as a theme for an event.

Other benefits exist for the hackathon event planners when partnering with a library. Hackathon planners should consider reaching out to libraries as they already serve as a cross-disciplinary event spaces, host many other outreach events, and are often connected to other campus and community stakeholders and communication outlets. Since students from all disciplines and colleges already use the library spaces on college campuses, they are an ideal location for fostering collaborations from different colleges and majors. Public libraries function as community gathering spots as well. As libraries consider hosting events, several articles provide overarching tips for planning and hosting hackathons and other time-bound events. ${ }^{59}$ Table 2 provides an overview of articles and the areas of coverage for planning topics. 
Table 2. Selected articles for tips on planning hackathon events based on common article theme areas

\begin{tabular}{|l|l|l|l|l|l|}
\hline Article author & $\begin{array}{l}\text { Location } \\
\text { details }\end{array}$ & $\begin{array}{l}\text { Sample } \\
\text { agenda }+ \\
\text { timelines }\end{array}$ & $\begin{array}{l}\text { Power and } \\
\text { computing }\end{array}$ & $\begin{array}{l}\text { Mentors/ } \\
\text { judging }\end{array}$ & $\begin{array}{l}\text { Further } \\
\text { readings }\end{array}$ \\
\hline Carruthers (2014) & $\mathrm{X}$ & $\mathrm{X}$ & $\mathrm{X}$ & $\mathrm{X}$ & \\
\hline $\begin{array}{l}\text { Nelson \& Kashyap } \\
(2014)\end{array}$ & $\mathrm{X}$ & $\mathrm{X}$ & $\mathrm{X}$ & $\mathrm{X}$ & $\mathrm{X}$ \\
\hline $\begin{array}{l}\text { Jansen-Dings, Dijk, } \\
\text { van Westen (2017) }\end{array}$ & $\mathrm{X}$ & $\mathrm{X}$ & & & $\mathrm{X}$ \\
\hline $\begin{array}{l}\text { Bogdanov \& Isaac- } \\
\text { Mendard (2016) }\end{array}$ & $\mathrm{X}$ & $\mathrm{X}$ & & $\mathrm{X}$ & \\
\hline $\begin{array}{l}\text { Nandi \& Mandernach } \\
\text { (2016) }\end{array}$ & $\mathrm{X}$ & & $\mathrm{X}$ & $\mathrm{X}$ & \\
\hline Grant (2017) & $\mathrm{X}$ & $\mathrm{X}$ & $\mathrm{X}$ & $\mathrm{X}$ & $\mathrm{X}$ \\
\hline
\end{tabular}

As library data becomes more open and reusable, hackathons will be a way to highlight data availability, promote its use and reuse, and reach out to the community. The issues present when considering library collections as potential hackathon themes are that libraries will need to ensure the data are cleaned and contain sufficient metadata so that the data are ready to use. Additionally, if there are programming language restrictions for ongoing maintenance by the library after the event, those should be specified when advertising the event. Ultimately, the libraries will likely not control the intellectual property (IP) of the tool or visualization developed, but several libraries have specified the ultimate IP as part of the event details either as open source or co-owned..$^{60}$ Often the goal of the event is the promotion of specific materials or building awareness of a collection rather than any biproduct created during the event. However, it is important for the library to be clear about their intent when advertising to participants. The collections-as-data movement will continue to evolve and there will be a multitude of library resources that could be mined for use at hackathons or other similar events.

While libraries provide an ideal location and have access to data that can be used for an event, they can also leverage their wealth of experts. Library staff can serve as judges, mentors, and connectors to the wider campus or community. Events could highlight specific expertise when hackathons focus on particular approaches (data visualization), processes (metadata management or documentation), or codesign of services (physical spaces). Table 3 provides examples of hackathon events from a variety of library contexts.

Hackathons are a great way for libraries to serve as a connector to others on campus or in their communities. If libraries are not interested or able to host an event themselves, library staff can act as mentors or event judges. At smaller schools, library staff can partner with other campus units to plan a hackathon; similarly, smaller public libraries could work with community organizations to host events. At a smaller scale if staffing is a concern or full hackathons are unrealistic, a coding contest or datathon, both of which typically have a shorter duration, might be an option. Edit-a-thons are even easier to host as they require only an introduction to the editing process, ample computer space (or laptop hook-ups), and a small food budget. Some edit-a-thon events happen in a single afternoon. 
Table 3. Selected hackathon event summaries from various library contexts based on themes and products of the event

\begin{tabular}{|c|c|c|c|c|c|c|}
\hline $\begin{array}{l}\text { Article } \\
\text { author }\end{array}$ & $\begin{array}{l}\text { Type of } \\
\text { library }\end{array}$ & $\begin{array}{l}\text { Size of } \\
\text { event }\end{array}$ & $\begin{array}{l}\text { Time } \\
\text { for } \\
\text { event }\end{array}$ & $\begin{array}{l}\text { Purpose of } \\
\text { event }\end{array}$ & $\begin{array}{l}\text { Role of the } \\
\text { library }\end{array}$ & Output \\
\hline $\begin{array}{l}\text { Carruthers } \\
\text { (2014) }\end{array}$ & $\begin{array}{l}\text { Public + } \\
\text { city }\end{array}$ & $\begin{array}{l}29 \\
\text { participants }\end{array}$ & 1 day & $\begin{array}{l}\text { Highlight } \\
\text { open data } \\
\text { from the } \\
\text { libraries }\end{array}$ & $\begin{array}{l}\text { Event space, } \\
\text { coffee + } \\
\text { pizza, emcee, } \\
\text { some prizes, } \\
\text { assessment }\end{array}$ & $\begin{array}{l}\text { Building } \\
\text { partnerships } \\
\text { with the city, } \\
\text { getting dataset } \\
\text { requests }\end{array}$ \\
\hline $\begin{array}{l}\text { Ward, } \\
\text { Hahn, } \\
\text { Mestre } \\
(2015)\end{array}$ & Academic & $\begin{array}{l}6 \text { teams; } 25 \\
\text { participants }\end{array}$ & $\begin{array}{l}2 \\
\text { weeks }\end{array}$ & $\begin{array}{l}\text { Develop } \\
\text { apps using } \\
\text { library data }\end{array}$ & $\begin{array}{l}\text { Event } \\
\text { sponsor, } \\
\text { mentor }\end{array}$ & $\begin{array}{l}\text { App } \\
\text { development for } \\
\text { library using } \\
\text { library data }\end{array}$ \\
\hline $\begin{array}{l}\text { Mititelu \& } \\
\text { Grosu } \\
(2016)\end{array}$ & Academic & $\begin{array}{l}100 \\
\text { participants }\end{array}$ & $\begin{array}{l}48 \\
\text { hours }\end{array}$ & $\begin{array}{l}\text { Bring } \\
\text { together } \\
\text { tech } \\
\text { students }\end{array}$ & Event space & $\begin{array}{l}\text { App } \\
\text { development for } \\
\text { sponsors }\end{array}$ \\
\hline $\begin{array}{l}\text { Nandi \& } \\
\text { Manderna } \\
\text { ch (2016) }\end{array}$ & Academic & $\begin{array}{l}200 \\
\text { participants }\end{array}$ & $\begin{array}{l}36 \\
\text { hours }\end{array}$ & $\begin{array}{l}\text { Bring } \\
\text { together } \\
\text { tech } \\
\text { students }\end{array}$ & $\begin{array}{l}\text { Event space, } \\
\text { planning } \\
\text { logistics, } \\
\text { judges }\end{array}$ & $\begin{array}{l}\text { Various apps, } \\
\text { not library } \\
\text { related }\end{array}$ \\
\hline $\begin{array}{l}\text { Baione } \\
\text { (2017) }\end{array}$ & $\begin{array}{l}\text { Private } \\
\text { museum }\end{array}$ & $\begin{array}{l}100 \\
\text { participants }\end{array}$ & 2 days & $\begin{array}{l}\text { Animate, } \\
\text { organize, } \\
\text { and enable } \\
\text { greater } \\
\text { access to } \\
\text { digitized } \\
\text { content } \\
\text { from the } \\
\text { library }\end{array}$ & $\begin{array}{l}\text { Create } \\
\text { challenges, } \\
\text { event space, } \\
\text { judges }\end{array}$ & $\begin{array}{l}\text { Open source } \\
\text { apps for GLAM } \\
\text { institutions }\end{array}$ \\
\hline $\begin{array}{l}\text { Theise } \\
\text { (2017) }\end{array}$ & $\begin{array}{l}\text { Academic } \\
+ \text { public }\end{array}$ & $\begin{array}{l}100 \\
\text { participants }\end{array}$ & $\begin{array}{l}2 \text { days } \\
+6 \\
\text { week } \\
\text { sprint }\end{array}$ & $\begin{array}{l}\text { Cultural } \\
\text { hackathon } \\
\text { to highlight } \\
\text { library data } \\
\text { and } \\
\text { resources }\end{array}$ & $\begin{array}{l}\text { Event space, } \\
\text { challenges, } \\
\text { datasets for } \\
\text { hacking }\end{array}$ & $\begin{array}{l}\text { Highlighted data } \\
\text { available for use, } \\
\text { created apps } \\
\text { focused on } \\
\text { library materials }\end{array}$ \\
\hline $\begin{array}{l}\text { Almogi et } \\
\text { al. (2019) }\end{array}$ & Academic & $\begin{array}{l}23 \\
\text { participants }\end{array}$ & 5 days & $\begin{array}{l}\text { Develop } \\
\text { linguistic } \\
\text { tools for } \\
\text { Buddhist } \\
\text { studies }\end{array}$ & $\begin{array}{l}\text { Provided } \\
\text { cleaned } \\
\text { datasets for } \\
\text { manipulation }\end{array}$ & $\begin{array}{l}\text { Linguistic tools } \\
\text { for Buddhist } \\
\text { studies }\end{array}$ \\
\hline
\end{tabular}

One area for iteration around these events relates to timing. While most hackathons last 24-36 hours, some are run over the course of a one- or two-month period where coding happens 
remotely with a few scheduled check-ins with mentors before judging and presentations. This notion of a remote event may have more appeal for collections-as-data-themed events as experts are more likely to be available for keynotes or mentoring. If the process instead of the product is the focus of the event, then providing a flexible structure may be more appealing to participants. If a library has more limited resources or capacity, stretching the event out over a longer period would allow for sustained interactions. However, libraries should be aware that the longer the event period, the greater the attrition of the participants.

An area for future research includes assessment of library participation in events. A couple of articles highlighted the value the libraries found in the events, but it is unclear whether the participants also gained value from the libraries. ${ }^{61}$ Typically, post-event surveys have focused on the participant experience or the overall event space, rather than whether it affected participants' view of the libraries, which would another area of interest for future research. ${ }^{62}$

\section{CONCLUSION}

In the realm of hackathons and libraries, originally hackathon themes were a way that vendors could highlight new content or improve interfaces. Libraries followed this trend and used events to reach out to constituents, make connections with their communities, and highlight evolving library services. With the growth of flexible spaces, ample technology support and more relaxed food policies, libraries have become ideal event locations. As the collections-as-data movement evolves, there will be more opportunities to develop services related to these data and other library data which would lend themselves easily as themes for hackathons, edit-a-thons, or datathons.

Libraries thinking about hosting events will need to weigh the amount of time and resources they want to invest with the intended goals of hosting an event. Planning is essential whether the library is the event host, a collaborator, or a sponsor of a hackathon. For those libraries that are unable to host a full hackathon, smaller events, such as a datathon or edit-a-thon, are possibilities to provide support without the same time and resource commitment. Given the growing popularity of hackathons and other coding contests, they may be a catch-all for solving several library issues simultaneously: updating the library's image as being more than book-centric, supporting the collections-as-data movement, and a new way of engaging community partners.

\section{ACKNOWLEDGEMENTS}

Thank you to Jody Condit Fagan for providing valuable suggestions on a draft of this paper and to the two anonymous reviewers whose feedback improved the quality of this manuscript.

\section{ENDNOTES}

${ }^{1}$ James K. Elmborg, "Libraries as the Spaces Between Us: Recognizing and Valuing the Third Space," Reference and User Services Quarterly 50, no. 4 (2011): 338-50.

2 “A Brief Open Source Timeline: Roots of the Movement," Online Searcher 39, no. 5 (2015): 44-45; Patrick Timony, "Accessibility and the Maker Movement: A Case Study of the Adaptive Technology Program at District of Columbia Public Library," in Accessibility for Persons with Disabilities and the Inclusive Future of Libraries, Advances in Librarianship, vol. 40, (Emerald Group Publishing Limited, 2015), 51-58; Kurt Schiller, “Elsevier Challenges Library Community," Information Today 28, no. 7 (July 2011): 10; Eric Lease Morgan, "WorldCat 
Hackathon," Infomotions Mini-Musings (blog), last modified November 9, 2008, http://infomotions.com/blog/2008/11/worldcat-hackathon/; Margaret Heller, "Creating Quick Solutions and Having Fun: The Joy of Hackathons," ACRL TechConnect (blog), last modified July 23, 2012, http://acrl.ala.org/techconnect/post/creating-quick-solutions-andhaving-fun-the-joy-of-hackathons.

${ }^{3}$ Clemens Neudecker, "Working Together to Improve Text Digitization Techniques: 2nd Succeed Hackathon at the University of Alicante," Impact Centre of Confidence in Digitisation blog, last updated April 22, 2014, https://www.digitisation.eu/succeed-2nd-hackathon/; Porter Anderson, "Futurebook Hack," Bookseller no. 5628 (June 20, 2014): 20-21; Sarah Shaffi, "Inaugural Hack Crowns its Diamond Project," Bookseller no. 5628 (June 20, 2014): 18-19.

${ }^{4}$ Rose Sliger Krause, James Rosenzweig, and Paul Victor Jr. "Out of the Vault: Developing a Wikipedia Edit-a-thon to Enhance Public Programming for University Archives and Special Collections," Journal of Western Archives 8, no. 1 (2017): 3; Stanislav Bogdanov and Rachel Isaac-Menard, "Hack the Library: Organizing Aldelphi [sic] University Libraries' First Hackathon," College and Research Libraries News 77, no. 4 (2016): 180-83; Matt Enis, "Civic Data Partnerships," Library Journal 145, no. 1 (2020): 26-28; Alex Carruthers, "Open Data Day Hackathon 2014 at Edmonton Public Library," Partnership: The Canadian Journal of Library \& Information Practice \& Research 9 no. 2 (2014): 1-13, https://doi.org/10.21083/partnership.v9i2.3121; Sarah Shujah, "Organizing and Embedding a Library Hackfest into a 1st Year Course," Information Outlook 18, no. 5 (2014): 32-48; Lindsay Anderberg, Matthew Frenkel, and Mikolaj Wilk, "Project Shhh! A Library Design Contest for Engineering Students," in American Society for Engineering Education 2018 Annual Conference Proceedings (2018): Paper ID 21058, https://cms.jee.org/30900.

${ }^{5}$ Michelle Demeter et al., "Send in the Crowds: Planning and Benefiting from Large-Scale Academic Library Events," Marketing Libraries Journal 2 no. 1 (2018): 86-95, https://bearworks.missouristate.edu/cgi/viewcontent.cgi?article=1089\&context=articles-lib.

${ }^{6}$ Jamie Lausch Vander Broek and Emily Puckett Rodgers, "Better Together: Responsive Community Programming at the UM Library," Journal of Library Administration 55, no. 2 (2015): 131-41; Arnab Nandi and Meris Mandernach, "Hackathons as an Informal Learning Platform," in SIGCSE 2016 - Proceedings of the 47th ACM Technical Symposium on Computing Science Education (February 2016): 346-51, https://doi.org/10.1145/2839509.2844590; Lindsay Anderberg, Matthew Frenkel, and Mikolaj Wilk, "Hack Your Library: Engage Students in Information Literacy Through a Technology-themed Competition," in American Society for Engineering Education 2019 Annual Conference Proceedings, (2019): Paper ID 26221, https://peer.asee.org/32883; Anna Grant, Hackathons: a Practical Guide, Insights from the Future Libraries Project Forge Hackathon (CarnegieUK Trust, 2017), https://www.carnegieuktrust.org.uk/publications/hackathons-practical-guide/; Carruthers, "Open Data Day Hackathon 2014 at Edmonton Public Library"; Chad Nelson and Nabil Kashyap, GLAM Hack-in-a-Box: A Short Guide for Helping You Organize a GLAM Hackathon (Digital Public Library of America, Summer 2014), http://dpla.wpengine.com/wpcontent/uploads/2018/01/DPLA HackathonGuide ForCommunityReps 9-4-14-1.pdf. 
${ }^{7}$ David Ward, James Hahn, and Lori Mestre, "Adventure Code Camp: Library Mobile Design in the Backcountry," Information Technology and Libraries 33, no. 3 (2014): 45-52; David Ward, James Hahn, and Lori Mestre, "Designing Mobile Technology to Enhance Library Space Use: Findings from an Undergraduate Student Competition," Journal of Learning Spaces 4, no. 1 (2015): 30-40.

${ }^{8}$ Ann Marie L. Davis, "Current Trends and Goals in the Development of Makerspaces at New England College and Research Libraries," Information Technology and Libraries 37, no. 2 (2018): 94-117, https://doi.org/10.6017/ital.v37i2.9825; Mark Bieraugel and Stern Neill, "Ascending Bloom's Pyramid: Fostering Student Creativity and Innovation in Academic Library Spaces," College \& Research Libraries 78, no. 1 (2017): 35-52; Elyssa Kroski, The Makerspace Librarian's Sourcebook (Chicago: ALA Editions, 2017); Angela Pashia, "Empty Bowls in the Library: Makerspaces Meet Service," College \& Research Libraries News 76 no. 2 (2015): 79-82; H. Michele Moorefield-Lang, "Makers in the Library: Case Studies of 3D Printers and Maker Spaces in Library Settings," Library Hi Tech 32, no. 4 (2014): 583-93; Adetoun A. Oyelude, "Virtual Reality (VR) and Augmented Reality (AR) in Libraries and Museums," Library Hi Tech News 35, no. 5 (2018) 1-4.

${ }^{9}$ Krause, Rosenzweig, and Victor Jr., "Out of the Vault"; Ed Yong, "Edit-a-thon Gets Women Scientists into Wikipedia," Nature News (October 22, 2012), https://doi.org/10.1038/nature.2012.11636; Angela L. Pratesi et al., "Rod Library Art+Feminism Wikipedia Edit-a-thon," Community Engagement Celebration Day (2018): 10, https://scholarworks.uni.edu/communityday/2018/all/10; Maitrayee Ghosh, "Hack the Library! a First Timer's Look at the 29th Computers in Libraries Conference in Washington, DC," Library Hi Tech News 31, no. 5 (2014): 1-4, https://doi.org/10.1108/LHTN-05-2014$\underline{0031 .}$

${ }^{10}$ Carruthers, "Open Data Day Hackathon 2014 at Edmonton Public Library”; Bob Warburton, “Civic Center," Library Journal 141, no. 15 (2016): 38.

${ }^{11}$ Matt Burton et al., Shifting to Data Savvy: The Future of Data Science in Libraries (project report, University of Pittsburgh, Pittsburgh, PA, 2018): 1-24, https://d-scholarship.pitt.edu/33891/.

12 Vander Broek and Rodgers, "Better Together"; Nandi and Mandernach, "Hackathons as an Informal Learning Platform"; Robin Camille Davis, "Hackathons for Libraries and Librarians," Behavioral \& Social Sciences Librarian 35, no. 2 (2016): 87-91; Bogdanov and Isaac-Menard, "Hack the Library"; Ward, Hahn, and Mestre, "Adventure Code Camp"; Ward, Hahn, and Mestre, "Designing Mobile Technology to Enhance Library Space Use"; Demeter et al., "Send in the Crowds"; Carruthers, "Open Data Day Hackathon 2014 at Edmonton Public Library."

${ }^{13}$ Vander Broek and Rodgers, "Better Together."

${ }^{14}$ Demeter et al., "Send in the Crowds."

${ }^{15}$ Nandi and Mandernach, "Hackathons as an Informal Learning Platform.”

${ }^{16}$ Eduard Mititelu and Vlad-Alexandru Grosu, "Hackathon Event at the University Politehnica of Bucharest," International Journal of Information Security \& Cybercrime 6, no. 1 (2017): 97-98; 
Orna Almogi et al., "A Hackathon for Classical Tibetan,"Journal of Data Mining and Digital Humanities, Episciences.org, Special Issue on Computer-Aided Processing of Intertextuality in Ancient Languages, hal-01371751v3 (2019): 1-10, https://idmdh.episciences.org/5058/pdf.

${ }^{17}$ Davis, "Hackathons for Libraries and Librarians."

${ }^{18}$ Ghosh, "Hack the Library!"

${ }^{19}$ Timony, "Accessibility and the Maker Movement"; Ward, Hahn, and Mestre, "Adventure Code Camp."

${ }^{20}$ Gérald Estadieu and Carlos Sena Caires, "Hacking: Toward a Creative Methodology for Cultural Institutions," (presented at the VIII Lisbon Summer School for the Study of Culture "Cuber+Cipher+Culture", September 2017); Andrea Valdez, "The Vatican Hosts a Hackathon," Wired Magazine, last updated March 7, 2018, https://www.wired.com/story/vaticanhackathon-2018/; Leonardo Moura de Araujo, "Hacking Cultural Heritage: The Hackathon as a Method for Heritage Interpretation," (PhD diss., University of Bremen, 2018): 181-231, 23538.

${ }^{21}$ Thomas Finley, "Innovation Lab: A Conference Highlight," Texas Library Journal 94, no. 2 (Summer 2018): 61-62.

${ }^{22}$ Grant, Hackathons: A Practical Guide.

${ }^{23}$ Warburton, "Civic Center."

${ }^{24}$ Warburton, "Civic Center."

${ }^{25}$ Aude Charillon and Luke Burton, "Engaging Citizens with Data the Belongs to Them," CILIP Update Magazine (November 2016).

${ }^{26}$ Enis, "Civic Data Partnerships."

${ }^{27}$ Carruthers, "Open Data Day Hackathon 2014 at Edmonton Public Library.”

${ }^{28}$ Kevin McArthur, Herb Lainchbury, and Donna Horn, “Open Data Hackathon How To Guide v. 1.0," October 2012, https://docs.google.com/document/d/1fBuisDTliBAz9u2tr7sgv6GdDLOV aHbafjqHXSkNB0/e dit?pli=1; David Eaves, “Open Data Day 2013 in Vancouver," eaves.ca (blog), March 11, 2013, https://eaves.ca/2013/03/11/open-data-day-2013-in-vancouver/.

${ }^{29}$ Bogdanov and Isaac-Menard, "Hack the Library."

${ }^{30}$ Shujah, "Organizing and Embedding a Library Hackfest into a 1st Year Course."

${ }^{31}$ Nancy Shin, Kathryn Vela, and Kelly Evans, "The Research Role of the Librarian at a Community Health Hackathon-A Technical Report," Journal of Medical Systems 44 (2020): 36.

${ }^{32}$ Geri Diorio, "Programming by the Book," Voices of Youth Advocates 35, no. 4, (2012): 326-327. 
${ }^{33}$ Lauren Barack and Matt Enis, "Where Teens Teach," School Library Journal (April 2016): 30.

${ }^{34}$ Nelson and Kashyap, GLAM Hack-in-a-Box.

${ }^{35}$ Lindsay Anderberg, Matthew Frenkel, and Mikolaj Wilk, "Hack Your Library: A Library Competition Toolkit," June 6, 2019, https://wp.nyu.edu/hackyourlibrary/; Anderberg, Frenkel, and Wilk, "Hack Your Library: Engage Students in Information Literacy Through a Technologythemed Competition."

${ }^{36}$ Anna Grant, Engage. Respond. Innovate. The Value of Hackathons in Public Libraries (CarnegieUK Trust, 2020), https://www.carnegieuktrust.org.uk/publications/engage-respond-innovatethe-value-of-hackathons-in-public-libraries/.

${ }^{37}$ Bogdanov and Isaac-Menard. "Hack the Library."

${ }^{38}$ Ward, Hahn, and Mestre, "Adventure Code Camp."

${ }^{39}$ Ward, Hahn, and Mestre, “Designing Mobile Technology to Enhance Library Space Use."

${ }^{40}$ Anderberg, Frenkel, and Wilk, "Project Shhh!"

${ }^{41}$ Anderberg, Frenkel, and Wilk, "Hack Your Library: Engage Students in Information Literacy Through a Technology-themed Competition."

${ }^{42}$ Bethany McGowan, "The Role of the University Library in Creating Inclusive Healthcare Hackathons: a Case Study with Design-thinking Processes," International Federation of Library Associations and Institutions 45, no. 3 (2019): 246-53, https://doi.org/10.1177/0340035219854214.

${ }^{43}$ Marco Büchler et al., "Digital Humanities Hackathon on Text Re-use 'Don't Leave Your Data Problems at Home!'” Electronic Text Reuse Acquisition Project, event held July 27-31, 2015, http://www.etrap.eu/tutorials/2015-goettingen/; Helsinki Centre for Digital Humanities, "Helsinki Digital Humanities Hackathon 2017 \#DHH17," event held May 15-19, 2017, https://www.helsinki.fi/en/helsinki-centre-for-digital-humanities/dhh-hackathon/helsinkidigital-humanities-hackathon-2017-dhh17.

${ }^{44}$ Antje Theise, "Open Cultural Data Hackathon Coding Da Vinci-Bring the Digital Commons to Life," in IFLA WLIC 2017 Wroclaw Poland, session 231-Rare Books and Special Collections (2017), http://library.ifla.org/id/eprint/1785.

${ }^{45}$ Almogi et al., "A Hackathon for Classical Tibetan."

${ }^{46}$ Samantha Fritz et al., "Fostering Community Engagement through Datathon Events: The Archives Unleased Experience," Digital Humanities Quarterly 15, no. 1 (2021): 1-13, http://digitalhumanities.org/dhq/vol/15/1/000536/000536.html.

${ }^{47}$ Tom Baione, "Hackathon \& 21st-Century Challenges.” Library Journal 142, no. 2 (2017): 14-17. 
${ }^{48}$ American Museum of Natural History, "Hack the Stacks," https://www.amnh.org/learnteach/adults/hackathon/hack-the-stacks, https://github.com/amnh/HackTheStacks/wiki, https://github.com/HacktheStacks.

${ }^{49}$ Andrea Valdez, "Inside the Vatican's First-Ever Hackathon: This is the Holy See of the 21 ${ }^{\text {st }}$ Century," Wired Magazine, March 12, 2018, https://www.wired.com/story/inside-vhacksfirst-ever-vatican-hackathon/.

${ }^{50}$ Museomix, “Concept,” accessed March, 29, 2021, https://www.museomix.org/en/concept/.

${ }^{51}$ Kristi Bergland, Kalan Knudson Davis, and Stacie Traill, "CatDoc HackDoc: Tools and Processes for Managing Documentation Lifecycle, Workflows, and Accessibility," Cataloging and Classification Quarterly 57, no. 7-8 (2019): 463-95.

52 Islandora Collaboration Group, “Templates: How to Run a Hack/Doc," last modified December 5, 2017, https://github.com/Islandora-CollaborationGroup/icg information/tree/master/templates how to run a hack doc.

${ }^{53}$ Gordon Dunsire, "Toward an Internationalization of RDA Management and Development," Italian Journal of Library and Information Science 7, no. 2 (May 2016): 308-31. http://dx.doi.org/10.4403/jlis.it-11708

${ }^{54}$ Nelson and Kashyap, GLAM Hack-in-a-Box.

${ }^{55}$ Hannah-Louise Clark, “Global History Hackathons Information,” accessed April 19, 2021, https://www.gla.ac.uk/schools/socialpolitical/research/economicsocialhistory/projects/glob al\%20historyhackathons/history\%20hackathons/.

${ }^{56}$ Gustavo Candela et al., "Reusing Digital Collections from GLAM Institutions,” Journal of Information Science (August 2020): 1-10, https://doi.org/10.1177/0165551520950246.

57 Thomas Padilla, “On a Collections as Data Imperative,” UC Santa Barbara, 2017, https://escholarship.org/uc/item/9881c8sv; Rachel Wittmann et al., "From Digital Library to Open Datasets," Information Technology and Libraries 38, no. 4 (2019): 49-61, https://doi.org/10.6017/ital.v38i4.11101; Sandra Tuppen, Stephen Rose, and Loukia Drosopoulou, "Library Catalogue Records as a Research Resource: Introducing 'a Big Data History of Music,'” Fontes Artis Musicae 63, no. 2 (2016): 67-88.

${ }^{58}$ Moura de Araujo, "Hacking Cultural Heritage."

${ }^{59}$ Grant, Hackathons: A Practical Guide; Grant, Engage. Respond. Innovate.; Joshua Tauberer, "Hackathon Guide," accessed March 26, 2021, https://hackathon.guide/; Alexander Nolte et al., "How to Organize a Hackathon-A Planning Kit," arXiv preprint arXiv:2008.08025 (2020), https://arxiv.org/abs/2008.08025v2; Ivonne Jansen-Dings, Dick van Dijk, and Robin van Westen, Hacking Culture: a How-to Guide for Hackathons in the Cultural Sector, Waag Society, (2017): 1-41. https://waag.org/sites/waag/files/media/publicaties/es-hacking-culturesingle-pages-print.pdf.

${ }^{60}$ Ward, Hahn, and Mestre, “Designing Mobile Technology to Enhance Library Space Use.” 
${ }^{61}$ McGowan, "The Role of the University Library in Creating Inclusive Healthcare Hackathons."

${ }^{62}$ Nandi and Mandernach, "Hackathons as an Informal Learning Platform"; Carruthers, "Open Data Day Hackathon 2014 at Edmonton Public Library." 